Reprod. Nutr. Dévelop., 1986, 26 (6), 1273-1280.

\title{
Adaptation of pancreatic lipase to the amount and nature of dietary lipids in the growing pig
}

\section{SIMOES NUNES}

with the assistance of Georgette BRACHET, C. PICOU and F. COINTEPAS

Laboratoire de Physiologie de la Nutrition, I.N.R.A., 78350 Jouy-en-Josas, France.

Summary. The purpose of the present study was to examine the adaptation of pancreatic lipase to the amount and nature of dietary lipids in the growing pig. Thirty pigs were distributed into three groups of 10 animals each. They were fed the same amount $(1.5 \mathrm{~kg} / \mathrm{pig} /$ day $)$ of either diet C $(3.5 \%$ lard, $3.5 \%$ sunflower oil, $67,7 \%$ starch $)$, diet $\mathrm{L}$ (21\% lard, $33.2 \%$ starch) or diet SO (21\% sunflower oil, $33.2 \%$ starch) for 12 days. The diets were isoenergetic and isonitrogenous. Pancreas weight relative to live-weight was highest in group $\mathrm{L}$. The pancreatic lipid content of the latter group exceeded that of groups $\mathrm{C}$ and SO by 53 and $39 \%$, respectively. The pancreatic protein content was similar in the three groups. The specific lipase activity of pancreatic tissue (U per $\mathrm{mg}$ of protein) in group SO was about 1.6-fold higher than that of group $L$ and about 3-fold higher than that of group $C(31.9,19$ and 11.6 , respectively). Specific amylase activity was higher in animals of group $C$ than in those of the other two groups (C : $1689 ; L: 1112 ; S 0: 984$ ), whereas no difference was observed in chymotrypsin activity. Specific trypsin activity was lowest in group L.

These results confirm the adaptation of pancreatic lipase and amylase to their respective substrates. Furthermore, it appears that lipase activity was more or less affected by the degree of unsaturation of lipids and that it was much higher for the same amount of triacylglycerols when the latter were rich in unsaturated fatty acids. The mechanisms involved have not been determined yet, but the possible physiopathological consequences of the increased pancreatic lipid content observed in pigs receiving triacylglycerol-rich diets (including especially saturated fatty acids) should be considered.

\section{Introduction.}

Pancreatic lipase was long considered as a non-adaptative enzyme (Bucko and Kopec, 1968) but, owing to improved determination techniques, it was demonstrated that lipase did adapt to the amount of lipids ingested in a large number of experiments and in many animal species (Behrman and Kare, 1969 ; Hulan and Bird, 1972 ; Mourot and Corring, 1979 ; Simoes Nunes et al., 1985). Thus, although the effect of dietary amounts of triacylglycerols on pancreatic exocrine secretion has been well established, little is known about the effect of the nature of the triacylglycerols ingested.

Is the adaptative response of the pancreas modulated or not by the degree of unsaturation of triacylglycerol fatty acids ? Up till now only two studies have been 
devoted to this question and both in only one animal species, the rat (DeschodtLanckman et al., 1971 ; Saraux et al., 1982). Opposite conclusions were drawn by these authors : according to Deschodt-Lanckman et al. (1971) unsaturated lipids increased pancreatic lipase activity, whereas Saraux et al. (1982) did not find that the degree of saturation of the dietary triacylglycerols affected this enzyme.

The purpose of our study was to examine pancreatic adaptation to the level and nature of dietary lipids by using diets rich in saturated fatty acids (lard) or unsaturated ones (sunflower oil). The experimental design used allowed us to determine whether or not consumption of large amounts of triacylglycerols led to a rise in pancreatic lipid content.

\section{Material and methods.}

Thirty growing Large-White pigs (15 males, 15 females) with an initial live weight of $25.5 . \pm 0.32 \mathrm{~kg}$ were used in this experiment.

Three isoenergetic and isonitrogenous diets were each given for 12 days to 10 animals : a control diet (C), a diet rich in saturated fatty acids (L) and a diet rich in unsaturated fatty acids (SO) ; the fatty acid composition of the lard and sunflower oil was analysed by HPLC (table 1). Daily feed intake was 1.2 $\mathrm{kg} / \mathrm{pig} /$ day the first 5 days and $1.5 \mathrm{~kg} / \mathrm{pig} /$ day the last 7 days. The daily amount

TABLE 1

Diet composition (p. 100).

\begin{tabular}{|c|c|c|c|}
\hline & $\begin{array}{c}\text { Control } \\
\mathrm{C}\end{array}$ & $\begin{array}{c}\text { Lard } \\
\mathrm{L}\end{array}$ & $\begin{array}{l}\text { Sunflower oil } \\
\text { SO }\end{array}$ \\
\hline Hydrochloric casein $\ldots \ldots \ldots \ldots \ldots \ldots \ldots$ & 17.2 & 17.2 & 17.2 \\
\hline Maize starch $\ldots \ldots \ldots \ldots$. & 67.7 & 33.2 & 33.2 \\
\hline Lard $\ldots \ldots \ldots$ & 3.5 & 21 & - \\
\hline Sunflower oil .... & 3.5 & - & 21 \\
\hline Colmacel cellulose $\ldots \ldots \ldots \ldots \ldots \ldots \ldots \ldots$ & 2 & 10 & 10 \\
\hline Vermiculite (mica) $\ldots \ldots \ldots \ldots \ldots \ldots \ldots$ & 2.5 & 15 & 15 \\
\hline Minerals $\ldots \ldots \ldots \ldots \ldots \ldots \ldots \ldots \ldots \ldots$ & 2.5 & 2.5 & 2.5 \\
\hline Vitamins $\ldots \ldots \ldots \ldots \ldots \ldots \ldots \ldots \ldots$ & 1 & 1 & 1 \\
\hline Antioxidant $\ldots \ldots \ldots \ldots \ldots \ldots \ldots \ldots \ldots \ldots$ & 0.1 & 0.1 & 0.1 \\
\hline $\begin{array}{l}\text { Crude protejn }(\%), \ldots \ldots \ldots \ldots \ldots \ldots \ldots \\
\text { Crude energy }(\mathrm{Cal} / \mathrm{kg}) \ldots \ldots \ldots \ldots \ldots\end{array}$ & $\begin{array}{l}15 \\
3944\end{array}$ & $\begin{array}{l}15 \\
4007\end{array}$ & $\begin{array}{l}15 \\
4007\end{array}$ \\
\hline
\end{tabular}

Fatty acid composition (in p. 100 of total methyl esters) of lard and sunflower oil.

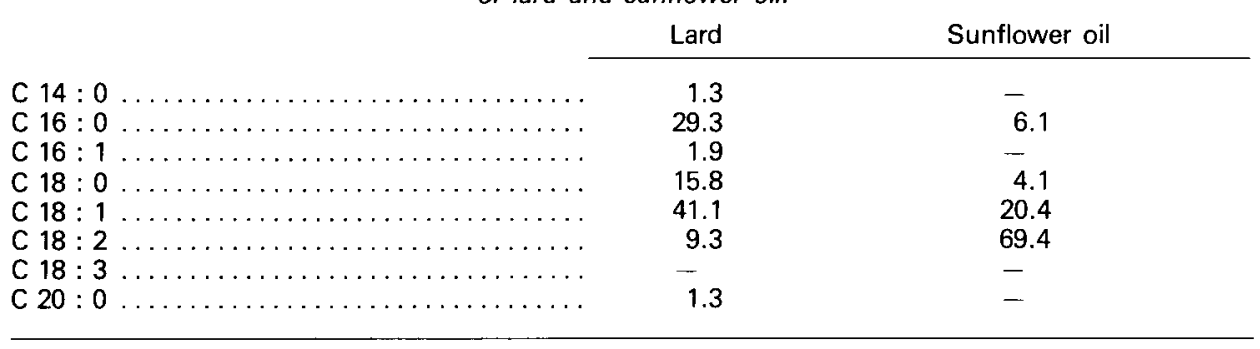


of feed was offered in two equal meals at 9.00 and $16.00 \mathrm{~h}$, respectively. Water was given ad libitum.

All the animals were sacrificed in the morning of Day 13 of the experiment after a fasting period of $18 \mathrm{~h}$. Immediately after slaughter the pancreas was removed, separated from the connective tissue, weighed and ground in distilled water $\left(6.7 \mathrm{ml} \mathrm{H} \mathrm{H}_{2} \mathrm{O} / \mathrm{g}\right.$ of pancreatic tissue). The homogenates thus obtained were used to determine pancreatic protein content as well as lipase, amylase, trypsin and chymotrypsin activities according to methods described elsewhere (Simoes Nunes and Corring, 1979). The total lipid content of the pancreas was measured according to Folch et al. (1957).

All data were interpreted statistically by analysis of variance (F-test).

\section{Results.}

\section{A. Feed intake, health and weight gain.}

All the animals ingested the amounts of feed indicated in the experimental protocol. None of them exhibited clinical symptoms of disease during the study. Daily mean gains (DMG) are reported in table 2 ; those of pigs fed the control diet were significantly higher than those of the animals offered the other two diets. The lowest DMG was recorded in pigs receiving $21 \%$ lard in their diet, but it was not significantly different from that of animals fed the diet containing $21 \%$ sunflower oil (266 \pm 45 and $302 \pm 34 \mathrm{~g} / \mathrm{d}$ ).

\section{B. Pancreatic characteristics.}

1. Pancreas weight, total pancreatic lipids. - Pancreas weight relative to live weight was significantly affected by diet composition (table 2 ) ; it was highest in animals fed $21 \%$ lard and lowest in those receiving the control diet.

TABLE 2

Daily mean gain (DMG), pancreas weight relative to live-weight, total lipid content and pancreatic protein level (expressed in total amount, per $\mathrm{g}$ of pancreas and per $\mathrm{kg}$ of live weight) according to diet composition.

\begin{tabular}{|c|c|c|c|c|}
\hline Parameters & $\begin{array}{l}\text { Control } \\
\text { (C) }\end{array}$ & $\begin{array}{l}\text { Lard } \\
\text { (L) }\end{array}$ & $\begin{array}{l}\text { Sunflower oil } \\
\text { (SO) }\end{array}$ & $\begin{array}{c}\text { Statistical } \\
\text { significance (F) }\end{array}$ \\
\hline DMG (g) $\ldots \ldots \ldots \ldots$ & $437 \pm 34^{(1) a(2)}$ & $266 \pm 45^{b}$ & $302 \pm 24^{b c}$ & $\begin{array}{l}\text { a-b } P<0.01 \\
\text { b-c } P<0.05\end{array}$ \\
\hline$\frac{\text { Pancreas weight }(\mathrm{g})}{\text { Live-weight }(\mathrm{kg})} \ldots$ & $1.80 \pm 0.05^{a}$ & $2.31 \pm 0.08^{b}$ & $2.06 \pm 0.07^{b c}$ & $\begin{array}{l}\text { a-b } P<0.001 \\
\text { a-c } P<0.05\end{array}$ \\
\hline$\frac{\text { Total lipids }(\mathrm{g})}{\text { Pancreas }(100 \mathrm{~g})}$ & $2.98 \pm 0.14^{a}$ & $4.57 \pm 0.09 b$ & $3.29 \pm 0.05^{a c}$ & a-b $P<0.001$ \\
\hline $\begin{array}{l}\text { Total proteins (mg) } \\
\text { Proteins (mg) }\end{array}$ & $11084 \pm 532^{\mathrm{a}}$ & $12811 \pm 758^{\mathrm{a}}$ & $11040 \pm 623^{a}$ & $\begin{array}{c}\mathrm{b}-\mathrm{P} \mathrm{P}^{\mathrm{P}}<0.05 \\
\text { N }\end{array}$ \\
\hline Pancreas $(g) \quad \cdots \cdots \cdots$ & $202 \pm 8 a$ & $186 \pm 9^{a}$ & $188 \pm 9^{a}$ & NS \\
\hline$\frac{\text { Proteins }(\mathrm{mg})}{\text { Live-weight }(\mathrm{kg})} \ldots \ldots \ldots$ & $363 \pm 19^{a}$ & $453 \pm 73^{b c}$ & $389 \pm 21^{a c}$ & a-b $P<0.05$ \\
\hline
\end{tabular}

(1) Mean \pm Sem of values obtained.

(2) Values with the same superscript (a, b or c) are not statistically different at the $5 \%$ level. 
The pancreatic lipid content of the controls was significantly lower than that of animals fed the diet containing $21 \%$ lard. The pancreas of the latter animals also exhibited a significantly higher lipid content than that of the groups receiving $21 \%$ sunflower oil.

2. Pancreatic protein content. - The protein content of the pancreas, expressed in total amount or in mg per $\mathrm{g}$ of pancreas (table 2), was very constant in the three groups of animals and did not show any significant difference. The pancreatic protein content expressed per $\mathrm{kg}$ of live weight, was highest in the group ingesting $21 \%$ lard, but this was mainly due to the low live weight of these animals at the end of the experiment.

3. Chymotrypsin and trypsin activities. - Chymotrypsin activity - either total, specific (per meg of protein) or per $\mathrm{g}$ of pancreas - was very similar and not different statistically in the three experimental groups (table 3 ).

Whatever the diet offered, total trypsin activity was similar in the three groups. Specific trypsin activity or per $\mathrm{g}$ of pancreas was lowest in pigs receiving $21 \%$ lard, the difference being statistically significant as compared to pigs ingesting the diet containing $21 \%$ sunflower oil.

4. Amylase activity. - The activity of this enzyme was very high in the controls, low in the pigs fed $21 \%$ lard and even lower in the group ingesting $21 \%$ sunflower oil (table 3 ). Whatever the mode of expression of amylase activity (total, specific or per $\mathrm{g}$ of pancreas), there was always a statistical difference between the control and the $21 \%$ sunflower oil groups. Because of the wider dispersion of the values in the control group and the lower final weight of the $21 \%$ lard group, the differences observed between the amylase activity of the latter group and that of the two others were not always significant.

5. Lipase activity. - Significant differences were observed between the lipase activity of the three groups (table 3 ).

The activity of the pancreatic lipolytic enzyme was very high in pigs receiving $21 \%$ sunflower oil, moderate in those fed the diet containing $21 \%$ lard and low in the controls. These observations concerned all forms of expression of enzyme activity (total, specific or per $\mathrm{g}$ of pancreas).

\section{Discussion and conclusion.}

In the present experimental conditions, growing pigs fed lipid-rich diets over a 12-day period showed lower mean gains than pigs fed a control diet. This was particularly marked with the diet containing $21 \%$ lard. However, it was found that the growth rate increased in pigs ingesting a peanut-rich diet as compared to those fed a lower lipidic diet (Henry and Rérat, 1964; Henry, 1974). This is in contradiction with the results of our experiment but this contradiction is only apparent, as the energy level of our three diets was the same, so that the higher growth rate recorded by the former authors can be imputed to an increase in the 


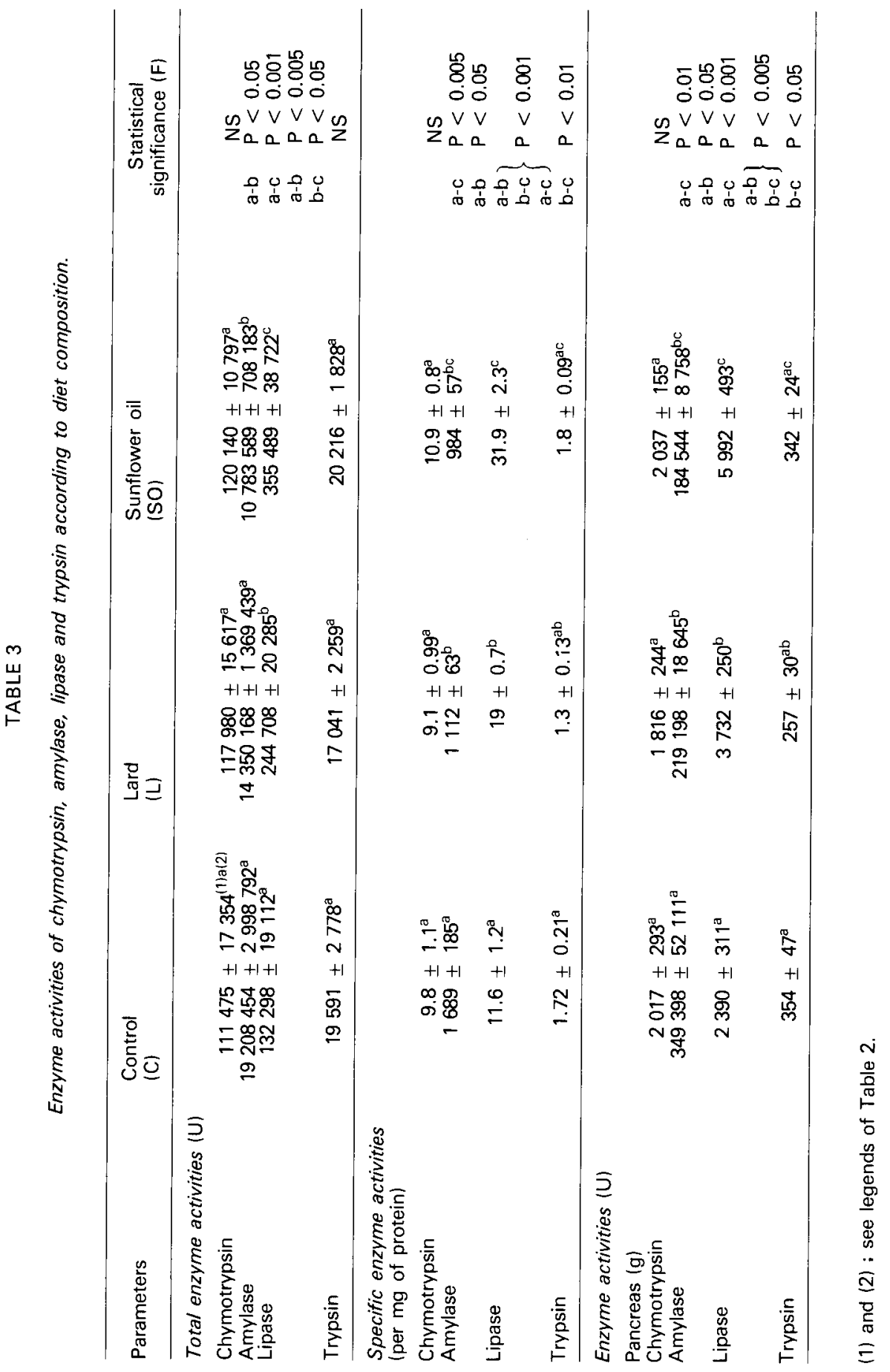


energy level of the diet used and hence to a larger ingestion of digestible energy.

The utilization of either $21 \%$ lard or sunflower oil in the diet led to an increase in pancreas weight relative to live weight (less marked with $21 \%$ sunflower oil). These differences were to a great extent due to the variable total lipid content of the pancreas. Thus, it appeared that ingestion of lipid-rich diets (especially those rich in saturated fatty acids) significantly increased the total lipid content of the pancreas. The possible long-term physiopathological consequences of this should be envisaged, as food for human consumption in most industrialized countries is very lipid-rich.

Many studies on the adaptation of pancreatic amylase and lipase to dietary carbohydrates and lipids were made with diets in which not only the supply of carbohydrates and lipids, but also of proteins, was different. Now, variations in the protein supply have not only a specific effect on pancreatic proteases (mainly chymotrypsin in pigs), but also a non-specific effect on all pancreatic hydrolases (Vandermeers et al., 1968 ; Corring and Saucier, 1972). In the present study, the dietary protein level was the same in all the experimental groups; only the supply of carbohydrates and lipids as well as the nature of the latter varied. This allowed us to clearly show the sensitivity of pancreatic amylase and lipase to changes in the proportions of their specific substrates in the diet. Pancreatic protein content and chymotrypsin activity were not modified by the diets used. These findings are in agreement with previous observations by Mourot and Corring (1979) and Simoes Nunes (1982).

The enzyme activity of trypsin in pigs is generally little affected by variations in the dietary protein supply, i.e. in its specific substrates (Corring and Saucier, 1972 ; Simoes Nunes, 1982). Ingestion of the diet containing $21 \%$ lard led to a particularly low trypsin activity. Such an effect was not observed either with $21 \%$ sunflower oil or with diets including similar levels of peanut oil administered to growing pigs (Mourot and Corring, 1979 ; Simoes Nunes, 1982). It seems that lard exerts a depressive effect on the activity of trypsin.

It has been well established that amylase adapts to dietary starch content, and our data confirm its inductibility by its substrate in pigs (Corring, 1975 ; Mourot and Corring, 1979 ; Simoes Nunes, 1982). In parallel, it appears that pancreatic amylase activity is also sensitive to the nature of dietary triacylglycerols. Amylase activity was low with the diet containing $21 \%$ sunflower oil. In rats, Deschodt-Lanckman et al. (1971) and Saraux et al. (1982) also observed that unsaturated fatty acid-rich triacylglycerols had a depressive effect on pancreatic amylase activity.

It appears to be essential to consider lipase activity determination in order to be able to separate the phenomenon of pancreatic lipase adaptation (under diet action) from a possible and isolated increase of the colipase level. The assay of lipase activity used concerns the determination of enzyme activity before and after the addition of colipase of pig origin. In previous studies and in the present one, we systematically observed that the values of lipase activity obtained before and after the addition of exogenous colipase were the same, i.e. that all the lipase activity present in the pancreatic tissue was measured. According to this, the observed variations of lipase activity with the diets offered to the pigs were the result of an increase in enzyme activity and not the indirect result of colipase 
adaptation. However, it must be remembered that in the pig, colipase also adapts to the fat content in the diet, but this is less evident than in the case of lipase (Mourot and Corring, 1979).

Pancreatic lipase was highly affected by the content and nature of dietary lipids. As compared to the control diet, its activity was 1.6 and 3-fold higher with diets containing $21 \%$ lard and $21 \%$ sunflower oil, respectively. Accordingly, there was a specific effect of the quality and quantity of dietary triacylglycerols on pancreatic lipase. The inductibility of lipase by the dietary lipid content confirmed previous data also obtained in pigs (Corring, 1975; Mourot and Corring, 1979 ; Simoes Nunes, 1982). Differences in the ability of triacylglycerols (saturated or unsaturated) to stimulate pancreatic lipase have only been studied in rats by Deschodt-Lanckman et al. (1971) and Saraux et al. (1982). Contradictory conclusions were drawn from these studies on differences in the sensitivity of lipase to the degree of unsaturation of the fatty acids of dietary triacylglycerols. Thus, Deschodt-Lanckman et al. (1971) showed that the inductibility of lipase by triacylglycerols was higher with those containing unsaturated fatty acids, while Saraux et al. (1982) did not observe such an effect. The results of our study seem to show that pig pancreatic lipase is not only specifically sensitive to the content but also to the nature of dietary triacylglycerols.

It may be concluded that the enzyme composition of the pig pancreas adapts to the carbohydrate and lipid content of the diet. The inductibility of pancreatic lipase also depends on the degree of unsaturation of the triacylglycerol fatty acids, i.e. inductibility is higher when the triacylglycerols are rich in unsaturated fatty acids (sunflower oil) than when they are rich is saturated fatty acids (lard).

Reçu en novembre 1985.

Accepté en septembre 1986.

Acknowledgements. This work was supported in part by a M.R.T. grant « Digestion et métabolisme des lipides "), contract No 83-C.0452.

Résumé. Adaptation de la lipase pancréatique à la teneur et à la nature des lipides alimentaires chez le porc.

L'objectif du travail rapporté a été d'examiner, chez le porc en croissance, l'adaptation de la lipase pancréatique à la quantité et à la nature des lipides du régime alimentaire. Trente porcs de $25,5 \pm 0,32 \mathrm{~kg}$ de poids vif initial ont été répartis en trois groupes de dix animaux chacun. Ils ont reçu respectivement le régime $C \quad 13,5 \%$ de saindoux $; 3,5 \%$ d'huile de tournesol; $67,7 \%$ d'amidon), le régime $L(21 \%$ de saindoux; $33,2 \%$ d'amidon) et le régime SO (21\% d'huile de tournesol ; $33,2 \%$ d'amidon). Les trois régimes (isoénergétiques et isoprotéiques) ont été alloués aux animaux en quantité égale $(1,5 \mathrm{~kg} /$ jour $/$ porc $)$ pendant douze jours. Sur le tissu pancréatique, prélevé à la fin de l'expérience, différents paramètres ont été déterminés.

Le poids du pancréas relatif au poids vif $s^{\prime}$ est montré le plus élevé dans le lot $L$. Le contenu en lipides totaux du pancréas de ces animaux était supérieur de $53 \%$ et de $39 \%$ respectivement à celui des lots $\mathrm{C}$ et $\mathrm{SO}$. La teneur en protéines pancréatiques est apparue identique dans les trois groupes d'animaux. L'activité spécifique (U/mg de protéines) de la lipase dans le lot SO était environ une fois et demie celle du lot $L$ et environ trois fois celle 
du lot $C$ (SO : 31,9; L : 19 et $C: 11,6)$. L'activité spécifique de l'amylase a été plus élevée chez les animaux $C$ que chez ceux des deux autres groupes ( $C: 1689 ; L: 1112$ et $S O$ : 984), tandis qu'aucune différence ne s'est révélée dans l'activité de la chymotrypsine. La trypsine a présenté l'activité spécifique la plus faible dans le lot $L$.

Ces résultats confirment, d'une part, l'adaptation de la lipase et de l'amylase pancréatiques à leurs substrats respectifs et montrent, d'autre part, que l'activité de la lipase pancréatique est plus ou moins inductible selon le degré d'insaturation des lipides. L'activité enzymatique de la lipase est beaucoup plus élevée chez le porc, pour la même quantité de triacylglycérols alimentaires, quand ceux-ci sont riches en acides gras insaturés. Les mécanismes impliqués dans ce phénomène restent à déterminer. Les éventuelles conséquences physiopathologiques de l'augmentation du contenu en lipides totaux du pancréas, observée chez le porc nourri avec des régimes riches en triacylglycérols (surtout saturés), méritent aussi d'être envisagées.

\section{References}

BEHRMAN H. R., KARE M. R., 1969. Adaptation of canine pancreatic enzymes to diet composition. J. Physiol., 205, 667-675.

BUCKO A., KOPEC Z., 1968. L'adaptation du pancréas à la nature des aliments. Son mécanisme. Cah. Nutr. Diét, XIV, 71-75.

CORRING T., 1975. Adaptation de la sécrétion du pancréas exocrine au régime alimentaire chez le porc. Physiologie comparée, étude expérimentale et mécanismes. Thèse Doct. ès-Sci. d'Etat Univ. Paris VI, $100 \mathrm{pp}$.

CORRING T., SAUCIER R., 1972. Sécrétion pancréatique sur porc fistulé. Adaptation à la teneur en protéines du régime. Ann. Biol. anim. Bioch. Biophys., 12, 233-241.

DESCHODT-LANCKMAN M., ROBBERECHT P., CAMUS J., 1971. Short-term adaptation of pancreatic hydrolases to nutritional and physiological stimuli in adult rat. Biochimie, 53, 789796.

FOLCH J., LEES M., SLOANE-STANLEY G. H., 1957. A simple method for the isolation and purification of total lipids from animal tissues. J. biol. Chem., 226, 497-509.

HENRY Y., 1974. Incorporation de proportions variables de matières grasses (huile d'arachide) dans le régime du porc en croissance-finition, en relation avec le taux de matières azotées. Ann. Zootech,, 23, 171-184.

HENRY Y., RÉRAT A., 1964. Variations des taux énergétiques et azotés dans l'alimentation du porc en croissance. Observations préliminaires. Ann. Biol. anim. Bioch. Biophys., 4, 263-271.

HULAN H., BIRD F., 1972. Effect of fat level in isonitrogenous diets on the composition of the avian pancreatic juice. J. Nutr., 102, 421-428.

MOUROT J., CORRING T., 1979. Adaptation of lipase-colipase system to dietary lipid content in pig pancreatic tissue. Ann. Biol. anim. Bioch. Biophys., 19, 119-124.

SARAUX B., GIRARD A., OUAGUED M., VACHER D., 1982. Response of the exocrine pancreas to quantitative and qualitative variations in dietary lipids. Am. J. Physiol, 243, 610-615.

SIMOES NUNES C., 1982. Lack of pancreatic enzyme adaptation to diet carbohydrates and lipids after proximal small intestine bypass in the pig. Digestion, 25, 57-58.

SIMOES NUNES C., CORRING T., 1979. Pancreatic exocrine secretion in the pig following test meals of different composition and intraduodenal loads of glucose and maltose. Horm. Metab. Res., 11, 346-351.

SIMOES NUNES C., CHARLET-LERY G., ALLAIN D., ROUGEOT J., 1985. Adaptation de la sécrétion pancréatique exocrine du vison à la composition du régime alimentaire. Reprod. Nutr. Dévelop., 25, 810.

VANDERMEERS A., KHAYAT M. H., RATHE J., CHRISTOPHE J., 1968. Vie moyenne de cinq hydrolases dans le pancréas du rat normal et en malnutrition protéique. Biochim. Biophys. Acta, 158, 448-458. 